\title{
Kepuasan Pemustaka Bersumber pada Nilai Perpustakaan: Studi Empiris pada Direktorat Perpustakaan Universitas Islam Indonesia
}

\section{Sungadi}

Universitas Islam Indonesia

sungadi@uii.ac.id

\section{Abstrak}

Penelitian ini bertujuan untuk mengetahui dan menganalisis kepuasan pemustaka yang bersumber dari nilai perpustakaan. Penelitian dilakukan di Universitas Islam Indonesia (UII) dengan menyebarkan kuesioner kepada mahasiswa yang kebetulan berkunjung ke perpustakaan sebanyak 135 responden sebagai sampel. Analisis data dilakukan dengan cara analisis korelasi Product Moment.

Hasil penelitian membuktikan, bahwa persepsi mahasiswa terhadap variabel nilai perpustakaan dalam kualifikasi tinggi dengan nilai persepsi sebesar 60,07 dan variabel kepuasan mahasiswa tergolong dalam kualifikasi tinggi pada angka persepsi sebesar 73,30. Sementara indikator nilai akademik dari variabel nilai perpustakaan dalam kualifikasi tinggi dengan angka persepsi sebesar 73,70 menduduki nilai tertinggi dan terendah terdapat pada nilai ekonomi dengan skor72,28. Selanjutnya indikator kecepatan layanan dari variabel kepuasan mahasiswa menempati persepsi tertinggi 77,59 dalam kualifikasi sangat tinggi dan terendah pada indikator empati pada kualifikasi tinggi dengan angka persepsi sebesar 70,19. Pada hasil pengujian korelasi, terdapat pengaruh antara nilai perpustakaan terhadap kepuasan mahasiswa UIl dengan angka pengaruh sebesar $72,40 \%(0,724)$ dengan nilai signifikansi $0,000<0,05(0,000)$ lebih kecil dari 0,05). Artinya hipotesis penelitian diterima dan besaran pengaruh kepuasan mahasiswa UII dari nilai perpustakaan sebesar $72,40 \%$, sementara masih ada faktor diluar nilai perpustakaan sebesar $27,60 \%$ yang mempengaruhi kepuasan mahasiswa.

\section{Kata kunci:}

kepuasan pemustaka, nilai perpustakaan, nilai akademik, nilai ekonomi, kecepatan pelayanan, empati

\section{Pendahuluan}

Secara tradisional, kualitas dan eksistensi perpustakaan ditandai dengan koleksi dalam bentuk cetak. Bukti kepemilikan koleksi perpustakaan dapat diukur melalui penyajian data dalam bentuk statistik (grafik atau tabel). Dengan semakin meningkatnya kebutuhan informasi, perpustakaan konvensional tidak lagi mampu memenuhi permintaan pelanggan terhadap informasi. Agar kebutuhan informasi bagi pelanggan dapat terpenuhi, maka perpustakaan perlu melakukan inovasi dan mengikuti perkembangan zaman, sehingga kualitas perpustakaan meningkat. Kualitas adalah filosofi dasar dan persyaratan layanan perpustakaan. Semua perpustakaan berusaha untuk memberikan kualitas layanan tertinggi untuk memenuhi permintaan pelanggan akan informasi.
Layanan berkualitas merupakan harapan bagi setiap pelanggan. Jika perpustakaan memberikan informasi yang tepat kepada pengguna yang tepat pada waktu yang tepat dan menyediakan fasilitas yang diperlukan sebagai sarana akses bagi pemustaka, maka dapat dikatakan perpustakaan mampu memberikan layanan berkualitas. Hal ini sejalan dengan pendapat Sharma (2001) yang menyatakan, bahwa layanan perpustakaan berkualitas berarti memuaskan permintaan setiap pengguna secara akurat, mendalam, dan cepat. Dia juga mengungkapkan bahwa konsep kualitas layanan terutama didasarkan pada kualitas layanan yang dirasakan oleh pelanggan. Lebih lanjut Grönroos (1990) menjelaskan ketika penyedia layanan memahami bagaimana layanan akan dievaluasi oleh pelanggan, menjadi mungkin untuk 
mengidentifikasi bagaimana mengelola evaluasi ini dan bagaimana mempengaruhi mereka dalam arah yang diinginkan. Sejumlah peneliti telah mencapai konsensus pada fakta bahwa kualitas layanan harus ditentukan dan diukur dari perspektif pelanggan (Brown dan Swartz, 1989, Schneider and White, 2004). Menurut Grönroos (1984), kualitas layanan adalah hasil dari proses evaluasi, di mana pelanggan membandingkan ekspektasinya dengan layanan yang dia rasakan telah diterima. Parasuraman, Zeithaml, dan Berry (1988, p. 15) setuju dengan gagasan ini, dan mereka mendefinisikannya sebagai "evaluasi keseluruhan dari perusahaan jasa spesifik yang dihasilkan dari membandingkan kinerja perusahaan dengan harapan umum pelanggan tentang bagaimana perusahaan dalam industri itu harus tampil."

Perpustakaan secara tradisional identik dengan fasilitas fisik yang berkonsentrasi dalam penyediaan koleksi tercetak untuk kepentingan membaca di antara kelompok pengguna tertentu (seperti perpustakaan perguruan tinggi) atau masyarakat umum. Namun, di era informasi digital seperti saat ini, pencari informasi untuk penelitian akademis atau menyelesaikan tugas akhir mahasiswa tidak bergantung pada kunjungan fisik ke perpustakaan. Pencarian referensi online mulai dilihat sebagai pengganti yang lebih efektif. Masalah ini bahkan sebagai ancaman bagi perpustakaan konvensional (Little, 2011; Odling-Smee, 2007; Rapp, 2011). Intinya, ruang perpustakaan berfungsi sebagai platform pusat distribusi dan sirkulasi untuk kegiatan berbagi buku. Seiring perkembangan zaman dan tuntutan pemakai, ruang perpustakaan secara fisik mengambil peran tambahan dengan menyediakan lingkungan yang nyaman, tenang dan aman untuk kegiatan belajar mandiri. Meskipun akses ke dalam ruang perpustakaan terbuka untuk umum atau untuk kelompok pengguna tertentu dalam komunitas tertentu, ruang perpustakaan menjadi tempat perlindungan bagi pecinta buku dalam lingkungan yang kondusif (Row Farr, 2017). Hal ini dimungkinkan terutama karena pengelolaan fasilitas di dalam ruang perpustakaan merupakan perkara yang penting yang tidak boleh dipandang sepele. Ketenangan di ruang perpustakaan secara umum merupakan unsur penting di semua jenis perpustakaan, kecuali untuk bagian tertentu di perpustakaan (missal ruang diskusi), karena pengguna seharusnya melakukan aktivitas membaca saja. Oleh karena itu, diskusi verbal biasanya dilarang di sebagian besar area gedung perpustakaan, dan pengguna dapat menikmati membaca atau bekerja sendiri tanpa terganggu oleh orang lain. Oleh karena itu, ada ikatan yang kuat antara fasilitas perpustakaan sebagai ruang fisik dan kepuasan belajar bagi pengguna yang telah terbukti menjadi kepentingan akademis (Bilandzic \& Foth, 2014; Cullen, 2014; Jolly \& White, 2016; Rudzioniene, 2014 ). Keberadaan perpustakaan, terutama perpustakaan perguruan tinggi, secara khusus dibangun untuk tujuan terjadinya kolaborasi yang memuaskan, antara fitur desain perpustakaan dan lingkungan belajar yang memungkinkan dapat memaksimalkan kepuasan belajar bagi pemustaka. Selain fungsi konvensional, Bilandzic dan Foth (2014) juga menunjukkan bahwa karakteristik arsitektur ruang perpustakaan dapat memainkan peran penting dalam menyoroti atribut sosial fasilitas perpustakaan dalam memperkuat interaksi sosial di antara pengunjung ke perpustakaan. Ruang belajar informal yang dimasukkan sebagai bagian dari lingkungan kampus dalam perpustakaan perguruan tinggi sama pentingnya dalam agenda pendidikan tinggi. Dengan cara ini, perpustakaan masih mempertahankan pembelajaran penting dan peran sosial di era informasi digital. Tim desain dan manajemen perpustakaan perguruan tinggi perlu memahami kebutuhan pengguna dan menghargai bahwa ada aspek yang tidak dapat digantikan oleh teknologi digital, termasuk komunikasi dan interaksi di antara pengguna, apresiasi budaya, seni, 
dan inspirasi di dalam fasilitas perpustakaan (Jolly \& White, 2016; Palfrey, 2015; Stojanovski, 2013). Adanya fakta, bahwa masih diragukan apakah digital raksasa seperti Google dapat mendigitalkan semua koleksi buku dengan cara yang hemat biaya (Fialkoff, 2011; Palfrey, 2015). Lebih penting lagi, administrator perguruan tinggi juga harus mengenali sifat unik ruang perpustakaan dalam mempromosikan budaya belajar mahasiswa, daripada memperlakukan ruang perpustakaan sebagai ruang fisik yang berlebihan yang dapat dikonsumsi oleh unit lain untuk kegiatan yang tidak terkait dengan pembelajaran dari waktu ke waktu.

Konsep kualitas layanan erat kaitannya dengan kepuasan pelanggan (Brady et al., 2002, Hernon dan Altman, 1998). Oliver (1997, p. 13) mendefinisikan kepuasan pelanggan sebagai pemenuhan respons pelanggan. Dia menilai bahwa fitur produk layanan, atau produk layanan itu sendiri, menyediakan tingkat kepuasan yang memuaskan terkait pemenuhan, termasuk tingkat di bawah atau di atas pemenuhan kebutuhan pemustaka. Secara khusus, akademisi dan praktisi sama-sama memiliki menunjukkan minat yang cukup besar dalam isu-isu yang mengelilingi pengukuran kualitas layanan dan konseptualisasi hubungan antara kualitas layanan dan kepuasan pelanggan (Brady et al., 2002). Sejumlah peneliti - seperti Hernon dan Altman (1998), lacobucci, Ostrom, dan Grayson (1995), dan Zeithaml, Berry, dan Parasuraman (1993) - telah jelas mengartikulasikan fakta bahwa kepuasan pelanggan adalah fungsi dari kualitas layanan.

Direktorat Perpustakaan Universitas Islam Indonesia dirancang dengan konsep modern dengan luas bangunan $\pm 7.000 \mathrm{~m}^{2}$ terdiri dari 5 lantai yang diperuntukkan bagi 25 ribu lebih pemustaka. Jumlah pemustaka yang sedemikan besar, tentunya membutuhkan sarana dan prasarana pendukung yang mampu memberikan kepuasan bagi pemakai tersebut. Dengan kata lain, perpustakaan perguruan tinggi harus memberikan kontribusi yang dapat diukur untuk kegiatan penelitian, pengajaran dan pembelajaran dari institusi yang menjadi tempat mereka belajar. Secara umum, layanan perpustakaan sebagai lembaga-lembaga sosial yang didirikan untuk melayani masyarakat akademik, karenanya perpustakaan perguruan tinggi perlu membuktikan nilainya kepada para pemangku kepentingan mereka. Artikel ini berusaha menganalisis berbagai pendekatan teoritis yang telah digunakan atau memberi informasi studi nilai di perpustakaan perguruan tinggi.

\subsection{Perumusan Masalah}

Berdasarkan asumsi di atas, peneliti ingin mengetahui dan menganalisis kepuasan pemustaka terhadap Nilai Perpustakaan Universitas Islam Indonesia, yang meliputi hal-hal antara lain:

1. Bagaimana persepsi responden terhadap nilai perpustakaan UII dan kepuasan mahasiswa?

2. Adakah pengaruh antara nilai perpustakaan UII terhadap kepuasan mahasiswa?

\subsection{Tujuan Penelitian}

1. Penelitian ini bertujuan untuk mengetahui dan menganalisis seberapa besar persepsi responden terhadap nilai perpustakaan UII dan kepuasan mahasiswa.

2. Mengetahui dan menganalisis pengaruh nilai perpustakaan UII terhadap kepuasan mahasiswa.

\subsection{Manfaat Penelitian Manfaat Teoritis}

Hasil penelitian ini diharapkan dapat menambah dan memperkaya kajian pada bidang kualitas layanan dan manajemen perpustakaan.

\section{Manfaat Praktis}

1. Dapat menambah wawasan peneliti dan pihak lain yang berminat mengkaji terhadap nilai kualitas layanan perpustakaan. 
2. Memberikan kontribusi bagi para pustakawan dan pengelola perpustakaan, untuk dapat meningkatkan terhadap kinerja mereka, sehingga diperoleh hasil layanan yang prima.

3. Dapat menambah rujukan bagi peneliti selanjutnya yang menaruh perhatian terhadap tema yang sama.

4. Memberikan masukan bagi institusi untuk perbaikan UII pada masa mendatang.

\section{Kajian Teoritis}

\subsection{Pendekatan Teoritis dalam Mempelajari Nilai Perpustakaan}

Dalam memeriksa nilai di perpustakaan, literatur juga dibagi secara luas menjadi dua kubu - studi nilai ekonomi dan studi dampak sosial seperti yang digambarkan pada Gambar. 1 di bawah ini. Kelompok pertama (nilai ekonomi) memiliki unsur yang menyatakan bahwa nilai perpustakaan dapat diukur secara finansial. Mereka berpendapat bahwa karena input ke layanan perpustakaan bersifat finansial, hasilnya dapat dinyatakan secara finansial. Pendekatan spesifik yang digunakan dalam pendekatan pertama ini adalah, 'laba atas investasi' atau 'analisis manfaat biaya', dan 'penilaian kontijensi'. Selain itu, pendekatan berikut telah disebutkan, (i) biaya waktu dan usaha, (ii) nilai informasi yang diperoleh, (iii) input \& output dan (iv) kalkulasi penilaian penggunaan perpustakaan (Walker, Haplin, Raplin, \& Chapman , 2012).

Kelompok kedua (dampak sosial), di sisi lain berpendapat bahwa perpustakaan adalah bagian dari materi sosial dan bahwa mereka menghasilkan nilai modal sosial (Town, 2015a, Town, 2015b) dengan kemakmuran sosial daripada keuntungan finansial. Terlepas dari dua klasifikasi yang muncul, studi nilai ekonomi dan studi nilai sosial ada satu tantangan, bahwa nilai layanan perpustakaan tidak berwujud dan bersifat intrinsik oleh karenanya sulit untuk diukur. Dalam paragraf berikut, pendekatan nilai ekonomi dijelaskan, diikuti oleh diskusi tentang

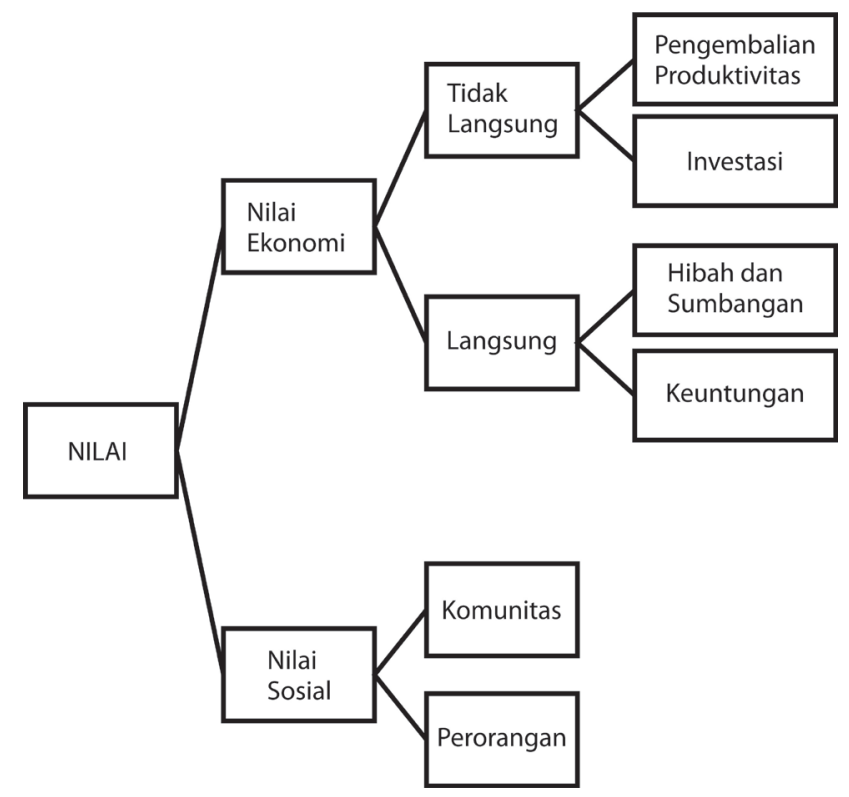

Gambar 1. Aspek Nilai

\subsection{Studi Nilai Ekonomi}

Studi ini juga disebut sebagai studi nilai keuangan dan mereka berusaha untuk menetapkan bahwa ada keuntungan finansial dalam berinvestasi dalam layanan perpustakaan. Studi pendekatan nilai ekonomi cenderung menggunakan metode kuantitatif dan berusaha untuk fokus pada manfaat langsung dan tidak langsung. Analisis manfaat biaya memperkirakan semua biaya yang terlibat dalam layanan dan juga manfaat yang mungkin diperoleh dari layanan tersebut, dan menyatakan nilai sebagai kekayaan bersih dalam mengurangi biaya dari manfaat yang diharapkan. Dengan cara ini, pendekatan memonetisasi layanan perpustakaan untuk mengekspresikan nilai layanan perpustakaan.

Metode Contingent Valuation digunakan untuk memperkirakan nilai baik non pemasaran melalui kuesioner kepada konsumen tentang preferensi mereka, dua perkiraan muncul, (i) kesediaan membayar dan kesediaan untuk menerima. Dalam kuesioner, responden disajikan dengan deskripsi materi yang akan dinilai dan perkiraan perubahan kuantitas atau kualitas unit, serta kendaraan pembayaran (Mitchell \& Carson, 1989). Penilaian kontijensi (CV) studi didasarkan pada pasar 
yang dibangun dan didasarkan pada niat yang dinyatakan dan situasi hipotetis dan yang sulit untuk diterapkan dan mungkin tidak mewakili keputusan dunia nyata. Namun demikian, kontijensi telah digunakan di perpustakaan umum, misalnya oleh perpustakaan Inggris dan juga di perpustakaan umum Norwegia. Dalam kasus British Library, tujuannya adalah untuk menemukan nilai langsung ke pengguna perpustakaan dan kemudian nilai yang secara tidak langsung dinikmati oleh warga Inggris. Kuesioner dirancang untuk menemukan estimasi nilai yang ditempatkan responden di perpustakaan. Dengan menggunakan metode penilaian kontingen, penelitian ini menetapkan bahwa lebih dari 50\% kegiatan perpustakaan mendukung Pendidikan Tinggi Inggris dan bahwa Perpustakaan Inggris menghasilkan nilai sekitar 4,4 kali tingkat pendanaan publiknya (British Library, 2004; Pung, Clarke, \& Patten , 2007; Tessler, 2013).

Return on investment (ROI) atau laba atas investasi adalah metode lain yang digunakan untuk menunjukkan bahwa dana yang diinvestasikan menghasilkan laba atau keuntungan dan dihitung sebagai rasio antara laba bersih dan investasi. Di perpustakaan, $\mathrm{ROI}$ telah dinyatakan sebagai rasio nilai yang dikembalikan ke institusi untuk setiap unit moneter yang diinvestasikan di perpustakaan (Tenopir, 2011: 272). Kekuatan dan kelemahan ROI di perpustakaan telah didokumentasikan oleh Matthews (2008).

Ada pendekatan ekonomi lain yang telah diadopsi untuk mencapai nilai perpustakaan, dan ini termasuk Surplus Konsumen, Model InputOutput, dan Manfaat Non-Pengguna. Pendekatan surplus konsumen mengukur dampak ekonomi melalui nilai keuntungan individu di atas harga yang mereka bayar. Surplus konsumen diukur melalui preferensi yang diungkapkan dari teknik preferensi yang dinyatakan. Pendekatan ini digunakan sebagai metode alternatif dalam mengukur dampak ekonomi dari British Library (Pung et al., 2007). Dua
Model Input-Output dan Manfaat Non-Pengguna berada pada tahap formatif berkaitan dengan penggunaannya dalam penilaian dan evaluasi perpustakaan (lihat Sbaffi \& Rowley, 2014).

\subsection{Studi Nilai Sosial}

Town (2015a: 32-34) menyediakan tiga pilar teoritis dari dampak sosial perpustakaan. Pertama, perpustakaan sebagai kontrak sosial, kedua perpustakaan sebagai modal sosial, dan ketiga perpustakaan sebagai organisme. Mengenai perpustakaan sebagai kontrak sosial bertumpu pada teori kontrak sosial, yang menunjukkan bahwa fitur realitas secara sosial dibangun. Town menyatakan, "sifat sosial perpustakaan memerlukan pengukuran untuk mencakup tindakan yang memberikan konsekuensi sosial". Perpustakaan sebagai modal sosial menyatakan bahwa perpustakaan adalah aset sosial kolektif, dan bahwa modal sosial adalah bangunan yang layak untuk dikelola, dikelola dan diukur oleh publik (Town, 2015b: 33). Pilar teoritis terakhir didasarkan pada hukum ilmu perpustakaan Ranganathan kelima (1931), bahwa "perpustakaan adalah organisme yang sedang tumbuh". Premisnya adalah bahwa perpustakaan tidak beroperasi secara terpisah dan visi mereka mencerminkan lingkungan yang berubah di mana mereka beroperasi secara terus menerus dan perlu untuk menyesuaikan layanan mereka sesuai tuntutan zaman. Dalam pendekatan ini, Town menekankan bahwa dampak sosial dan kontribusi kemasyarakatan dapat digunakan untuk mengukur nilai perpustakaan dan membenarkan keberadaan mereka.

Studi dampak sosial menjelaskan bahwa perpustakaan adalah konstruksi sosial dan karenanya menghasilkan nilai modal sosial. Dengan kata lain, penggunaan layanan perpustakaan memiliki dampak di luar batas-batas dinding mereka. Ini secara tepat dinyatakan oleh Town, 2011, Town, 2015a sebagai 'transenden benefit' yang didefinisikan sebagai nilai di luar kebutuhan atau permintaan mendesak. Ini adalah manfaat 
di luar tembok perpustakaan dan disebut sebagai manfaat tidak langsung. Contoh manfaat sosial atau nilai yang disumbangkan oleh perpustakaan dirangkum oleh Rooney-Browne (2011). Manfaat ini termasuk, warga yang berpengetahuan, kohesi sosial, keterlibatan masyarakat, mempromosikan nilai-nilai kewarganegaraan, berkontribusi pada jejaring sosial, meningkatkan peluang hidup, pemberdayaan dan meningkatkan harga diri.

Tantangan yang ada dalam studi dampak sosial adalah sulitnya menghubungkan layanan perpustakaan dengan pencapaian hasil ini (Pateman \& Pateman, 2017). Mungkin ada penyebab lain yang mengarah pada pencapaian hasil-hasil sosial ini, sebab dan akibatnya tidak jelas. Metode kualitatif telah digunakan untuk mengukur manfaat sosial atau tidak langsung dari perpustakaan dan metode ini termasuk wawancara, kuesioner, dan survei (Poll, 2003). Sebagai contoh, kuesioner digunakan oleh Yanez (2014: 87) di mana para pengguna ditanya bagaimana mereka menganggap perpustakaan universitas atau riset berkontribusi pada nilai-nilai sosial eksternal yang tidak terkait dengan upaya akademis mereka. Nilai-nilai kemasyarakatan ini termasuk (i) mencari informasi tentang hobi, (ii) belajar bahasa asing, (iii) mengembangkan ide bisnis, (iv) membantu dalam mencari pekerjaan dan, (v) membantu meningkatkan keterampilan profesional, dan lain-lainnya.

\subsection{Studi Nilai Akademik di Perpustakaan}

Banyak perpustakaan telah bereksperimen dengan dua pendekatan, masing-masing yang dibahas adalah studi nilai ekonomi, dan studi dampak sosial. Wacana perpustakaan akademis tentang nilai juga telah dibentuk oleh persyaratan untuk penyelarasan layanan dengan tujuan dan sasaran institusional. Untuk memenuhi permintaan yang bersaing seperti itu, White (2008: 499) menyatakan, "perpustakaan memberikan kepada para pemangku kepentingan dan pelanggan untuk memenuhi kebutuhan layanan yang sesuai dengan harapan pelanggan. Dalam menanggapi tantangan yang kompetitif perlu dilakukan pemilihan layanan terbaik bagi pelanggan perpustakaan. Pemangku kepentingan sudah seharusnya berinovasi terhadap berbagai jenis layanan informasi. Tuntutan ini yang menyebabkan perpustakaan sudah sepantasnya meningkatkan keselarasan layanan mereka, dengan tujuan kelembagaan dan dalam rangka menunjukkan nilai perpustakaan kepada para pemustaka dan pemangku kepentingan di atasnya (rektor/wakil rektor bidang akademik).

Para peneliti terus mengeksplorasi kerangka kerja bagaimana perpustakaan perguruan tinggi dapat menunjukkan nilai akedemik kepada para pemustaka yang dilayani. Sementara itu, tampaknya studi nilai di perpustakaan perguruan tinggi pasca 2010 telah mempengaruhi nilai dalam penelitian perpustakaan perguruan tinggi saat ini. Sejak penetapan agenda penelitian dalam studi nilai akademik oleh studi Oakleaf, telah terjadi peningkatan karya yang berpusat pada elemen-elemen spesifik (pengganti nilai) dari nilai perpustakaan perguruan tinggi - misalnya seperti retensi siswa, pengajaran fakultas dan reputasi kelembagaan. Dengan cara ini, nilai dalam wacana perpustakaan akademik telah dipecah menjadi elemen-elemen nilai kecil bagi para pelanggan tertentu dari perpustakaan-perpustakaan ini. Masih ada kesempatan bagi perpustakaan perguruan tinggi untuk menunjukkan nilai ke tujuan sosial yang lebih luas.

\subsection{Nilai Kepuasan Pelanggan}

Kepuasan pelanggan adalah perasaan senang atau kecewa seseorang yang berasal dari perbandingan antara kesannya terhadap kinerja (atau hasil) suatu produk dan harapan-harapannya (Kotler, 2017). Kepuasan merupakan fungsi dari kesan kinerja dan harapan. Jika kinerja di bawah harapan, pelanggan tidak puas jika kinerja memenuhi harapan, maka pelanggan akan puas. Jika kinerja melebihi harapan, maka pelanggan 
menjadi sangat puas.

Kualitas Pelayanan adalah suatu keadaan dimana kondisi baik atau buruk yang dirasakan oleh pengguna. Pelayanan baik akan berakibat puas bagi pemakai, sebaliknya pelayanan yang buruk akan berakibat kecewa bagi pemakai. Oleh Zeithami (dalam bukunya yang berjudul “Delivering Quality Service. Balancing Customer Perceptions and Expectations, 1990 : 21 -22)" dalam Sedarmayanti (2000:205) menyatakan bahwa tolok ukur kualitas pelayanan dapat diukur oleh 10 sub variabel (dimensi), yaitu : Tangibles( berwujud), Reliability (keandalan), Responsiveness (keesponsivan), Competence (pengetahuan dan keterampilan), Courtesy (perilaku), Credibility (kejujuran), Security (keamanan), Access (kemudahan hubungan), Communications (komunikasi), dan Understanding the Customer (mengerti kebutuhan pengguna). Ke-10 (sepuluh) komponen sebagai tolok ukur kualitas pelayanan tersebut antara lain:

Komponen pertama adalah Tangibles (berwujud). Komponen pertama ini menyangkut peralatan, perlengkapan, dan personil perpustakaan. Yang termasuk dalam komponen pertama ini misalnya menyangkut luas ruang perpustakaan, letak/ lokasi perpustakaan, jumlah koleksi, jadwal pelayanan, komputer anjungan, Air Conditioner (AC) dan sarana penunjang lainnya. Komponen kedua adalah Reliability (kehandalan). Komponen kedua ini berkaitan erat dengan kecepatan dalam melakukan pelayanan dan pelayanan dilakukan dengan tidak membedakan antara pemakai satu dengan pemakai lainya. Dengan kata lain pelayanan dilakukan secara adil. Kecepatan pelayanan dapat terwujud apabila didukung oleh sarana yang memadai, misalnya kualitas cetakan barcode mudah dibaca dengan scanner. Komponen ketiga adalah Responsiveness (keresponsipan). $\mathrm{Hal}$ ini erat kaitannya dengan pelayanan yang menyenangkan (kesadaran memberikan pelayanan), dan penguasaan terhadap tugas pegawai. Komponen keempat adalah Competence (pengetahuan dan keterampilan). Komponen ini meliputi pegawai mampu menjalankan tugas dan terampil terhadap pekerjaannya. Komponen kelima adalah Courtesy (perilaku). Komponen ini terdiri atas tindakan pegawai secara sopan kepada pemakai (ramah dan bersahabat), dan tanggap keinginan pelanggan. Komponen keenam adalah Credibility (kejujuran). Kejujuran seseorang akan memberikan dampak yang baik terhadap kualitas layanan. Terutama pada perpustakaan yang masih menggunakan sistem layanan tertutup, kejujuran petugas sangat diperlukan. Komponen ketujuh adalah Securrity (keamanan). Perpustakaan harus dapat memberikan jaminan keamanan terhadap barang milik pemakai, dengan menyediakan lockerlocker yang memadai. Disamping itu komponen ini juga menyangkut masalah kebijakan dalam mengambil keputusan kepada mahasiswa yang mempunyai masalah dengan perpustakaan, misalnya penetapan denda yang oleh mahasiswa dianggap sangat memberatkan baginya, dan kebijakan terhadap penggantian buku pinjaman yang hilang. Komponen kedelapan adalah Access (kemudahan hubungan). Petugas harus mampu menampung semua aspirasi/aduan dan mudah untuk mengadakan kontak dengan pelanggan. Komponen kesembilan adalah Communications (komunikasi). Komponen ini meliputi aspek kemampuan pegawai untuk pandai memikat pelanggan, dan rajin memberikan informasi terbaru kepada pelanggan. Komponen kesepuluh adalah Understanding the Customer (mengerti kebutuhan pelanggan). Menyangkut masalah kemampuan memenuhi kebutuhan pemakai, dan mampu memberikan pelayanan yang menjadi keinginan pelanggan.

Menurut Parasuraman dalam Lupiyoadi (2001:148), terdapat lima dimensi kualitas pelayanan sebagai berikut:

1. Tangibles atau bukti fisik, yaitu kemampuan 
suatu organisasi dalam menunjukkan eksistensinya kepada pihak eksternal. Penampilan dan kemampuan sarana dan prasarana fisik organisasi dan keadaan lingkungan sekitarnya adalah bukti nyata dari pelayanan yang diberikan oleh pemberi jasa. Ini meliputi fasilitas fisik (gedung), perlengkapan dan peralatan yang dipergunakan (teknologi), serta penampilan pegawainya.

2. Reliability atau keandalan, yaitu kemampuan organisasi (perusahaan) untuk memberikan pelayanan sesuai yang dijanjikan secara akurat dan terpercaya. Kinerja harus disesuaikan untuk pelanggan, seperti ketepatan waktu, pelayanan yang sama untuk semua pelanggan tanpa kesalahan, sikap simpatik.

3. Responsiveness atau ketanggapan, yaitu kemauan untuk membantu dan memberikan pelayanan yang cepat dan tepat kepada pelanggan, dengan penyampaian informasi yang jelas. Membiarkan konsumen menungu tanpa aanya suatu alasan yang jelas menyebabkan persepsi yang negatif dalam kualitas pelayanan.

4. Assurance atau jaminan dan kepastian, yaitu pengetahuan, kesopansantunan dan kemampuan pegawai untuk menumbuhkan rasa percaya para pelanggan perusahaan (organisasi). Dimana jaminan ini terdiri dari beberapa komponen; komunikasi, kredibilitas, keamanan, kompetensi dan sopan santun.

5. Empathy, yaitu memberikan perhatian yang tulus dan bersifat indiviual atau bersifat pribadi yang diberikan kepada para pelanggan dengan berupaya memahami keinginan konsumen. Suatu perusahaan (organisasi) diharapkan memiliki pengertian dan pengetahuan tentang pelanggan, memahami kebutuhan pelanggan secara spesifik, serta memiliki waktu pengoperasian yang nyaman bagi pelanggan.

\section{Metode Penelitian}

\subsection{Lokasi Penelitian}

Penelitian dilakukan di Direktorat Perpustakaan Universitas Islam Indonesia Yogyakarta. Pemilihan lokasi penelitian ini dengan mempertimbangkan beberapa aspek antara lain: masalah yang diteliti berada di Universitas Islam Indonesia, Peneliti bekerja di Universitas Islam Indonesia, dan dalam rangka efisiensi biaya, waktu dan tenaga.

\subsection{Populasi, Sampel dan Model Penentuan Sampel}

Dalam penelitian ini yang dimaksud dengan populasi adalah mahasiswa yang berkunjung ke Direktorat Perpustakaan sebagai subyek penelitian. Jumlah rata-rata pengunjung pada tahun 2017 sebesar 357.592 orang rata-rata per hari 1.490 orang. Sementara jumlah peminjam koleksi selama tahun 2017 sebesar 337.758 orang rata-rata per hari 1.407 orang dan besaran koleksi yang dipinjam sebanyak 460.820 eksemplar rerata per hari 1.920 eksemplar (https://library.uii.ac.id/statistics/ diakses 1 Desember 2018 pukul 13:11 WIB). Sampel yang ideal dari populasi 1.490 dengan taraf kesalahan $5 \%$ adalah 279 dengan catatan bahwa populasi berdistribusi normal. Bila sampel tidak berdistribusi normal, misalnya populasi homogen (dalam penelitian ini populasinya adalah pada kategori homogen mengingat populasi yang diambil berdasarkan mahasiswa yang aktif berkunjung ke Direktorat Perpustakaan UII), maka jumlah sampel yang diperlukan 1\% sudah dapat mewakili (Sugiyono, 2010: 70-71). Peneliti mengambil 170 mahasiswa sebagai sampel, akan tetapi data yang masuk dan diisi secara lengkap hanya 135 orang, maka 135 mahasiswa tersebut yang digunakan sebagai sampel. Teknik sampling yang digunakan adalah Insidental Sampling yakni teknik penentuan sampel dengan mempertimbangkan responden yang aktif dan yang secara kebetulan mengunjungi perpustakaan pada saat angket diedarkan. 
Responden/subjek penelitian sengaja ditujukan kepada mahasiswa yang aktif dan yang kebetulan berkunjung ke Direktorat Perpustakaan UII dengan pertimbangan bahwa mereka akan memberikan jawaban secara obyektif.

Angket yang disebarkan sebanyak 175 paket, dikembalikan dengan jawaban lengkap 135 paket (77,14\%), dikembalikan dengan jawaban tidak lengkap 12 paket $(6,86 \%)$, dan tidak dkembalikan 28 paket (16\%).

\subsection{Jenis Data, Sumber Data dan Teknik Pengumpulan Data \\ Data Primer}

Yaitu data yang diperoleh dengan cara melalui observasi kegiatan, keadaan, suasana yang ada di Perpustakaan, dan kemudian dibuat kuesioner. Data yang diperlukan dalam penelitian ini adalah data primer, yaitu data yang diperoleh langsung dari responden (subyek penelitian). Adapun teknik pengumpulan data dilakukan dengan cara mengamati dan menghitung jumlah skor yang terdapat pada quesioner hasil penelitian.

\section{Data Skunder}

Yaitu data yang diperoleh dengan cara membaca dan mengumpulkan berbagai bahan pustaka untuk menunjang penelitian ini.

\subsection{Teknik Analisis Data}

Sesuai dengan tujuan penelitian, data yang diperoleh dari lapangan akan dianalisis secara deskriptif kuantitatif yaitu dengan memaparkan data-data yang ada sedetail mungkin dengan memvisualiasikan ke dalam sebuah tabel, kemudian dilakukan pembahasan secara keseluruhan sehingga dapat diketahui dan dianalisis, kemudian dapat ditarik suatu kesimpulan.

\subsection{Pengukuran Variabel}

Survey kepuasan pemustaka terhadap Nilai Perpustakaan Universitas Islam Indonesia, dapat diukur dengan melalui indikator sebagai berikut:
Tabel 1: Pengukuran Variabel

\begin{tabular}{|c|c|}
\hline VARIABEL & INDIKATOR-INDIKATOR \\
\hline $\begin{array}{l}\text { Nilai } \\
\text { Perpus- } \\
\text { takaan }\end{array}$ & $\begin{array}{l}\text { a. Nilai Ekonomi: (i) biaya, waktu, dan } \\
\text { usaha, (ii) nilai informasi yang } \\
\text { diperoleh, (iii) input \& output dan } \\
\text { (iv) kalkulasi penilaian penggunaan } \\
\text { perpustakaan. } \\
\text { b. Nilai Sosial: (i) mencari informasi } \\
\text { tentang hobi, (ii) belajar bahasa } \\
\text { asing, (iii) mengembangkan ide } \\
\text { bisnis, (iv) membantu dalam mencari } \\
\text { pekerjaan dan, (v) membantu } \\
\text { meningkatkan keterampilan } \\
\text { profesional. } \\
\text { c. Nilai Akademik: (i) keaktivan } \\
\text { mahasiswa, (ii) pengajaran fakultas, } \\
\text { dan (iii) reputasi kelembagaan. }\end{array}$ \\
\hline $\begin{array}{l}\text { Kepuasan } \\
\text { Mahasiswa }\end{array}$ & $\begin{array}{l}\text { 1. Kecepatan petugas dalam melayani } \\
\text { mahasiswa } \\
\text { 2. Keramahan petugas dalam melayani } \\
\text { mahasiswa } \\
\text { 3. Kemampuan petugas dalam melayani } \\
\text { mahasiswa } \\
\text { 4. Responsiveness atau ketanggapan } \\
\text { petugas } \\
\text { 5. Dapat memberikan jaminan layanan } \\
\text { yang memuaskan } \\
\text { 6. Kesiapan dalam memberikan } \\
\text { bantuan atas kesulitan yang dihadapi } \\
\text { mahasiswa } \\
\text { 7. Tata susunan koleksi (keteraturan } \\
\text { urutan koleksi di rak buku) } \\
\text { 8. Kedisiplinan petugas }\end{array}$ \\
\hline
\end{tabular}

\subsection{Hipotesis}

Dari uraian di atas dapat dirumuskan hipotesis, bahwa terdapat pengaruh antara nilai perpustakaan terhadap kepuasan mahasiswa UII.

\section{Hasil Peneltian}

\subsection{Karakteristik Responden}

Dari 135 responden sebagai subyek penelitian ditemukan data sebagaimana disajikan pada Tabel 2.

Responden yang memberikan tanggapan terhadap penelitian ini paling banyak adalah mahasiswa angkatan 2016 sebanyak 43 orang (31.85\%), kemudian disusul angkatan 2014 sebanyak 40 mahasiswa (29.63\%), angkatan 2013 sejumlah 21 orang (15.56\%), angkatan 2015 
menduduki urutan selanjutnya dengan jumlah 16 orang (11.85\%), angkatan 2012 sejumlah 10 orang (7.41\%), sementara itu angkatan 2011 menduduki ranking paling sedikit, dengan angka 5 orang (3.7\%).

\begin{tabular}{|c|c|c|c|c|}
\hline No & $\begin{array}{l}\text { Data } \\
\text { Demografi }\end{array}$ & Kriteria & Jumlah & $\begin{array}{l}\text { Persentase } \\
\text { (\%) }\end{array}$ \\
\hline \multirow[t]{7}{*}{1} & \multirow{7}{*}{$\begin{array}{l}\text { Tahun } \\
\text { Angkatan }\end{array}$} & 2011 & 5 & 3.7 \\
\hline & & 2012 & 10 & 7.41 \\
\hline & & 2013 & 21 & 15.56 \\
\hline & & 2014 & 40 & 29.63 \\
\hline & & 2015 & 16 & 11.85 \\
\hline & & 2016 & 43 & 31.85 \\
\hline & & Jumlah & 135 & 100 \\
\hline \multirow[t]{11}{*}{2} & \multirow{11}{*}{$\begin{array}{l}\text { Asal dari } \\
\text { Fakultas }\end{array}$} & FTI & 56 & 41.48 \\
\hline & & FMIPA & 24 & 17.78 \\
\hline & & FPSB & 22 & 16.30 \\
\hline & & FTSP & 17 & 12.59 \\
\hline & & D3 FE & 6 & 4.44 \\
\hline & & $\mathrm{FH}$ & 6 & 4.44 \\
\hline & & MTI & 4 & 2.96 \\
\hline & & FE & - & - \\
\hline & & FIAI & - & - \\
\hline & & & - & - \\
\hline & & Jumlah & 135 & 100 \\
\hline \multirow[t]{3}{*}{3} & \multirow[t]{3}{*}{$\begin{array}{l}\text { Jenis } \\
\text { Kelamin }\end{array}$} & Laki-laki & 52 & 38.52 \\
\hline & & Perempuan & 83 & 61.48 \\
\hline & & Jumlah & 135 & 100 \\
\hline
\end{tabular}

Sumber: data primer diolah $\mathrm{N}=135,2017$

Sementara responden paling banyak berasal dari Fakultas Teknologi Industri (FTI) sebanyak 56 orang (41.48\%), diikuti dari FMIPA 24 orang (17.78\%), FPSB 22 orang (16.30\%), FTSP 17 orang (12.59\%), FH dan D3 Ekonomi masing-masing 6 orang (4.44\%), Magister Teknologi Industri 4 orang (2.96\%). Mahasiswa dari FE, FIAI dan FK masing-masing nol (0) pengunjung, hal ini dapat terjadi ada beberapa kemungkinan, antara lain pada saat dilakukan survey secara kebetulan mahasiswa ke-3 fakultas tidak ada yang berkunjung ke perpustakaan. Atau bisa jadi, mahasiswa dari ke-3 fakultas tersebut ada yang mendapatkan angket, akan tetapi tidak sempat mengembalikan pada tempat yang telah ditentukan.

Responden berjenis kelamin laki-laki berjumlah 52 orang (38.52\%) dan berjenis perempuan sebanyak 83 orang (61.48\%). Mahasiswa berjenis kelamin perempuan masih mendominasi dalam mengunjungi perpustakaan, yaitu sebesar $61.48 \%$, sedangkan mahasiswa laki-laki hanya sebesar 8.52 $\%$ saja.

\subsection{Persepsi Kepuasan Pemustaka}

Hasil penelitian diambil berdasarkan jawaban kuesioner sejumlah 135 responden yang disebarkan kepada Mahasiswa yang aktif dan yang kebetulan berkunjung ke Direktorat Perpustakaan UII dan datanya akan dimasukkan ke dalam suatu tabel frekuensi. Dari tabel tersebut kemudian diketahui berapa besar persentase dari data yang memiliki hubungan antara satu dengan lainnya. Langkah selanjutnya adalah melakukan analisis data dari hasil pengolahan (tabulasi) data tersebut dalam bentuk interpretasi atau dalam bentuk penjabaran data.

Dalam penelitian ini diajukan pertanyaan/ pernyataan yang harus dijawab oleh responden sebanyak 6 butir. Dari hasil tabulasi, maka diperoleh hasil sebagai berikut :

Tabel 3: Kecepatan dalam Melayani

$$
\mathrm{N}=135 \text { (2017) }
$$

\begin{tabular}{l|lll}
\hline $\begin{array}{l}\text { No. } \\
\text { Urut }\end{array}$ & $\begin{array}{l}\text { Prosedur } \\
\text { Pelayanan } \\
\text { Sirkulasi Mudah } \\
\text { dan Cepat }\end{array}$ & $\begin{array}{l}\text { Frekuensi } \\
\text { (F) }\end{array}$ & $\begin{array}{l}\text { Persentase } \\
\text { (\%) }\end{array}$ \\
\hline 1 & $\begin{array}{l}\text { Sangat Tidak Sesuai } \\
\text { (STS) }\end{array}$ & 6 & 4.44 \\
2 & Tidak Sesuai (TS) & 9 & 6.67 \\
3 & Sesuai (S) & 91 & 61.41 \\
4 & Sangat Sesuai (SS) & 29 & 21.48 \\
& Jumlah & $\mathbf{1 3 5}$ & $\mathbf{1 0 0}$ \\
\hline
\end{tabular}

Sumber data : primer

Dari Tabel 3 di atas yang menyatakan bahwa prosedur pelayanan (pinjam, kembali, perpanjang, dan bayar denda) mudah dan cetak dipersepsikan responden terletak pada daerah sesuai sebanyak 91 orang (61.41\%). Artinya bahwa 61.41\% pemustaka merasakan adanya kesesuaian (setara dengan kategori puas) dengan kecepatan petugas 
Direktorat Perpustakaan UII dalam melayani pemustaka. Sementara itu $21.48 \%$ mahasiswa sangat puas, sedangkan hanya $6.67 \%$ tidak puas, dan $4.44 \%$ merasakan sangat tidak puas.

Tabel 4: Tata Susunan Koleksi di Rak Buku N = 135 (2017)

\begin{tabular}{l|lll}
\hline $\begin{array}{l}\text { No. } \\
\text { Urut }\end{array}$ & $\begin{array}{l}\text { Tata Susunan } \\
\text { Koleksi di Rak } \\
\text { Buku }\end{array}$ & $\begin{array}{l}\text { Frekuensi } \\
\text { (F) }\end{array}$ & $\begin{array}{l}\text { Persentase } \\
(\%)\end{array}$ \\
\hline 1 & $\begin{array}{l}\text { Sangat Tidak } \\
\text { Sesuai (STS) }\end{array}$ & 7 & 5.19 \\
2 & Tidak Sesuai (TS) & 21 & 15.56 \\
3 & Sesuai (S) & 82 & 60.74 \\
4 & Sangat Sesuai & 25 & 18.52 \\
& (SS) & $\mathbf{1 3 5}$ & $\mathbf{1 0 0}$ \\
\hline
\end{tabular}

Sumber data : primer

Dari Tabel 4 di atas yang menyatakan bahwa susunan buku di rak dalam kondisi teratur, sehingga memberikan kemudahan dalam menemukan buku yang dicari, $(60.74 \%)$ dinilai oleh pemustaka dalam kondisi sesuai. Semenetara itu $18.52 \%$ mahasiswa menilai sangat sesuai, $15.56 \%$ mahasiswa menilai tidak sesuai, dan $5.19 \%$ pemustaka menyatakan sangat tidak sesuai. Artinya bahwa petugas direktorat perpustakaan masih perlu meningkatkan kinerjanya dalam melakukan shelving (penataan kembali buku di rak).

Tabel 5: Kesiapan Petugas Membantu Mencari Buku di Rak (Empati) $N=135(2017)$

\begin{tabular}{llll}
\hline $\begin{array}{l}\text { No. } \\
\text { Urut }\end{array}$ & $\begin{array}{l}\text { Kesiapan Petugas } \\
\text { Membantu Mencari } \\
\text { Buku di Rak (Empati) }\end{array}$ & $\begin{array}{l}\text { Frekuensi } \\
\text { (F) }\end{array}$ & $\begin{array}{l}\text { Persentase } \\
\text { (\%) }\end{array}$ \\
\hline 1 & $\begin{array}{l}\text { Sangat Tidak Sesuai } \\
\text { (STS) }\end{array}$ & 2 & 1.48 \\
2 & Tidak Sesuai (TS) & 28 & 20.74 \\
3 & Sesuai (S) & 85 & 62.96 \\
4 & Sangat Sesuai (SS) & 20 & 14.81 \\
& Jumlah & $\mathbf{1 3 5}$ & $\mathbf{1 0 0}$ \\
\hline
\end{tabular}
Sumber data : primer

Dari Tabel 5 di atas yang menyatakan bahwa 'petugas selalu memberikan bantuan yang diperlukan (empati) ketika pemustaka mengalami kesulitan dalam mencari buku di rak', terletak pada daerah sesuai (62.96\%), merasa tidak sesuai sebesar $20.74 \%$, sangat sesuai $14.81 \%$ dan sangat tidak sesuai sebesar $1.48 \%$. Artinya bahwa empati terhadap pemustaka bagi pegawai Direktorat Perpustakaan UII saat ini dirasakan oleh mahasiswa dalam kondisi memuaskan (sesuai), walaupun baru mencapai $62.96 \%$ saja. Dalam kondisi seperti ini, sudah sewajarnya apabila petugas perpustakaan perlu meningkatkan empatinya terhadap pemustaka.

Tabel 6: Sikap Ramah Petugas

$$
\mathrm{N}=135 \text { (2017) }
$$

\begin{tabular}{|c|c|c|c|}
\hline $\begin{array}{l}\text { No. } \\
\text { Urut }\end{array}$ & $\begin{array}{c}\text { Keramahan } \\
\text { Petugas }\end{array}$ & $\begin{array}{l}\text { Frekuensi } \\
\text { (F) }\end{array}$ & $\begin{array}{c}\text { Persentase } \\
\text { (\%) }\end{array}$ \\
\hline 1 & $\begin{array}{l}\text { Sangat Tidak } \\
\text { Sesuai (STS) }\end{array}$ & 4 & 2.96 \\
\hline 2 & $\begin{array}{l}\text { Tidak Sesuai } \\
\text { (TS) }\end{array}$ & 17 & 12.59 \\
\hline 3 & Sesuai (S) & 87 & 64.44 \\
\hline \multirow[t]{2}{*}{4} & $\begin{array}{l}\text { Sangat Sesuai } \\
\text { (SS) }\end{array}$ & 27 & 20.00 \\
\hline & Jumlah & 135 & 100 \\
\hline
\end{tabular}

Sumber data : primer

Dari Tabel 6 di atas yang menyatakan bahwa 'Petugas selalu ramah dan murah senyum', terletak pada kategori sesuai (64.44\%), mahasiswa yang merasa sangat sesuia sebesar $20.00 \%$, tidak sesuai $12.59 \%$ dan sangat tidak sesuai sebesar $2.96 \%$. Artinya bahwa tingkat keramahan terhadap mahasiswa bagi pegawai Direktorat Perpustakaan UII saat ini dirasakan oleh mahasiswa dalam kondisi memuaskan, walaupun baru mencapai $64.44 \%$ saja. Dalam kondisi seperti ini, sudah sewajarnya apabila petugas perpustakaan UII perlu meningkatkan keramahannya dan selalu urah senyum terhadap pemustaka.

Tabel 7: Ketepatan Waktu (Disiplin)

$$
\mathrm{N}=135 \text { (2017) }
$$

\begin{tabular}{c|ccc}
\hline $\begin{array}{c}\text { No. } \\
\text { Urut }\end{array}$ & $\begin{array}{c}\text { Ketepatan } \\
\text { Waktu } \\
\text { (Disiplin) }\end{array}$ & $\begin{array}{c}\text { Frekuensi } \\
\text { (F) }\end{array}$ & $\begin{array}{c}\text { Persentase } \\
\text { (\%) }\end{array}$ \\
\hline 1 & $\begin{array}{l}\text { Sangat Tidak } \\
\text { Sesuai (STS) }\end{array}$ & 0 & \\
\hline
\end{tabular}




\begin{tabular}{|c|c|c|c|}
\hline 2 & $\begin{array}{l}\text { Tidak Sesuai } \\
\text { (TS) }\end{array}$ & 12 & 8.89 \\
\hline 3 & Sesuai (S) & 98 & 72.59 \\
\hline 4 & $\begin{array}{l}\text { Sangat } \\
\text { Sesuai (SS) }\end{array}$ & 25 & 18.52 \\
\hline & Jumlah & 135 & 100 \\
\hline
\end{tabular}

Sumber data : primer

Pada Tabel 7 di atas yang menyatakan bahwa 'Petugas Direktorat Perpustakaan UII selalu siap melayani sesuai dengan jam layanan yang sudah ditentukan (disiplin)', terletak pada daerah sesuai (72.59\%), merasa sangat sesuai sebesar $18.52 \%$, tidak sesuai $8.89 \%$ dan sangat tidak sesuai sebesar $0 \%$. Artinya bahwa kedisiplinan petugas Direktorat Perpustakaan UII saat ini dirasakan oleh mahasiswa dalam kategori sesuai (memuaskan), walaupun baru mencapai $72.59 \%$ saja.

\subsection{Persepsi Pemustaka terhadap Nilai Perpustakaan}

Pada penelitian ini, kategori Nilai Perpustakaan diklasifikasi dalam 3 nilai, yaitu nilai ekonomi, nilai sosial, dan nilai akademik. Dari olah data ditemukan hasil seperti berikut.

Tabel 8: Persepsi Pemustaka terhadap Nilai Perpustakaan

\begin{tabular}{c|lrr}
\multicolumn{4}{|c}{$\mathrm{N}=135(2017)$} \\
\hline $\begin{array}{c}\text { No. } \\
\text { Urut }\end{array}$ & $\begin{array}{c}\text { Nilai } \\
\text { Perpustakaan }\end{array}$ & $\begin{array}{c}\text { Frekuensi } \\
\text { (F) }\end{array}$ & $\begin{array}{c}\text { Persentase } \\
\text { (\%) }\end{array}$ \\
\hline 1 & Nilai Ekonomi & 32 & 23.70 \\
2 & Nilai Sosial & 48 & 35.56 \\
3 & Nilai Akademik & 55 & 40.74 \\
& Jumlah & $\mathbf{1 3 5}$ & $\mathbf{1 0 0}$ \\
\hline
\end{tabular}

Sumber data : primer

Pada Tabel 8 tampak bahwa persepsi mahasiswa terhadap Nilai Perpustakaan Universitas Islam Indonesia paling dominan terletak pada aspek nilai akademik sebesar $40.74 \%$, aspek nilai sosial sebesar $35.56 \%$ dan aspek nilai ekonomi sebesar $23.70 \%$.

Nilai ekonomi perpustakaan pada studi ini meliputi: (i) keseimbangan yang diperoleh mahasiswa terhadap biaya, waktu, dan usaha yang di keluarkan; (ii) nilai informasi yang diperoleh merupakan investasi yang sangat bermanfaat dalam menunjang proses penyelesaian kuliah; (iii) dengan biaya kuliah yang sudah dikeluarkan oleh mahasiswa, akan diperoleh informasi yang optimal sehingga prestasi belajar dapat dicapai secara maksimal.

Selanjutnya nilai perpustakaan pada aspek nilai sosial terdiri dari ketersedian koleksi perpustakaan yang dapat menunjang hobi, peningkatan berbahas asing, pengembangan bisnis dan wirausaha, dan koleksi untuk peningkatan keterampilan profesional. Selain itu pemustaka juga menghendaki adanya jaringan kerjasama dengan lembaga penyedia lowongan kerja, sehingga pemustaka dapat terbantu dengan jasa layanan tersebut. Disamping itu pemustaka juga memandang perlu adanya jasa layanan di perpustakaan dalam bentuk peningkatan kemampuan berbahasa asing bagi pemustaka.

Sementara pada aspek nilai akedemik perpustakaan, mahasiswa menilai bahwa: (i) keaktivan kegiatan kemahasiswaan di kampus menurut pandangan mereka tidak mengganggu penyelesaian studi tepat waktu; (ii) pembelajaran fakultas sudah saatnya perlu menjalin kerjasama dengan perpustakaan secara online; (iii) reputasi Perpustakaan UII sudah dapat disetarakan dengan perguruan tinggi lainnya, bahwa pada aspek tertentu perpustakaan UII lebih unggul.

\section{Pembahasan}

\subsection{Uji Validitas}

Uji validitas bertujuan untuk mengukur sejauh mana ketepatan suatu alat ukur melakukan fungsi ukurnya. Teknik yang digunakan untuk uji validitas adalah Pearson Product Moment. Pengujian validitas dilakukan dengan responden sebanyak 135 responden. Dalam pengujian ini koefisien korelasi kritis diperoleh dari tabel distribusi $r$ pada taraf signifikansi sebesar $5 \%(0,05)$ diperoleh nilai $r_{\text {tabel }}=0,176$. Uji signifikansi dilakukan dengan membandingkan nilai $r_{\text {hitung }}$ dengan $r_{\text {tabel }}$ Jika $r$ hitung (untuk $r$ tiap butir pertanyaan terhadap skor total) lebih besar dari $r$ tabel, maka butir atau 
pertanyaan tersebut dikatakan valid. Hasil Uji Validitas dapat ditunjukkan pada tabel berikut:

Tabel 7: Hasil Uji Validitas

$\mathrm{N}=135$ (2017)

\begin{tabular}{l|cccc}
\hline \multicolumn{1}{c|}{ Variabel } & Item & $\mathbf{r}_{\text {tabel }}$ & $\begin{array}{c}\text { Koefisien } \\
\text { Korelasi }\end{array}$ & Keterangan \\
\hline Kepuasan & Soal1 & 0.176 & 0.634 & Valid \\
& Soal2 & 0.176 & 0.638 & Valid \\
& Soal3 & 0.176 & 0.760 & Valid \\
& Soal4 & 0.176 & 0.740 & Valid \\
& Soal5 & 0.176 & 0.689 & Valid \\
Nilai & Soal6 & 0.176 & 0.599 & Valid \\
\hline & Soal1 & 0.176 & 0.466 & Valid \\
& Soal2 & 0.176 & 0.529 & Valid \\
& Soal3 & 0.176 & 0.647 & Valid \\
& Soal4 & 0.176 & 0.647 & Valid \\
& Soal5 & 0.176 & 0.665 & Valid \\
& Soal6 & 0.176 & 0.658 & Valid \\
& Soal7 & 0.176 & 0.617 & Valid \\
& Soal8 & 0.176 & 0.469 & Valid \\
& Soal9 & 0.176 & 0.574 & Valid \\
& Soal10 & 0.176 & 0.620 & Valid \\
& Soal11 & 0.176 & 0.515 & Valid \\
\hline
\end{tabular}

Sumber: Data primer olahan, 2017

Dari Tabel 7 di atas dapat diketahui besarnya koefisien korelasi $\left(\mathrm{r}_{\text {hitung }}\right)$ dari seluruh butir pertanyaan terdiri dari 6 butir pertanyaan untuk variabel kepuasan (Y), dan 11 butir pertanyaan untuk variabel Nilai Perpustakaan $(\mathrm{X})$ terbukti valid. Data seluruh butir pertanyaan dari hasil hitungan tersebut menunjukkan bahwa $r_{\text {hitung }}$ lebih besar daripada $r_{\text {tabel }}\left(r_{\text {hitung }}>r_{\text {tabel }}\right)$. Dengan demikian seluruh item pertanyaan variabel layak digunanakan untuk penelitian selanjutnya.

\subsection{Uji Reliabilitas}

Uji Reliabilitas dilakukan untuk mengetahui sejauh mana alat ukur dapat memberikan hasil yang konsisten bila digunakan untuk mengukur obyek yang sama dengan alat ukur yang sama. Teknik yang digunakan untuk menilai reliabilitas adalah Cronbach's Alpha (a), dengan cara menyebarkan angket/kuesioner kepada Mahasiswa Universitas Islam Indonesia yang berkunjung ke Direktorat
Perpustakaan UII. Suatu instrumen penelitian dapat dikatakan reliabel (andal), jika alpha (a) lebih besar dari 0,60 (Ghozali, 2005: 42). Hasil pengujian reliabilitas dapat disajikan pada tabel berikut:

Tabel 8: Hasil Pengujian Reliabilitas

\begin{tabular}{l|ccc}
\multicolumn{4}{c}{$\mathrm{N}=135(2017)$} \\
\hline \multicolumn{1}{c|}{ Variabel } & $\begin{array}{c}\text { Koef. Alpha } \\
\text { Cronbach (a) }\end{array}$ & $\begin{array}{c}\text { Nilai } \\
\text { Kritis }\end{array}$ & Keterangan \\
\hline $\begin{array}{l}\text { Nilai } \\
\text { Perpustakaan }\end{array}$ & 0.796 & 0.6 & Reliabel \\
$\begin{array}{l}\text { Kepuasan } \\
\text { Mahasiswa }\end{array}$ & 0.756 & 0.6 & Reliabel \\
\hline
\end{tabular}

Sumber : Data primer olahan, 2017

Berdasarkan ringkasan hasil uji reliabilitas seperti yang tersaji dalam Tabel 8 di atas, dapat diketahui bahwa nilai koefisien Cronbach's Alpha (a), pada seluruh variabel lebih besar dari 0.6. Dengan demikian maka seluruh butir pertanyaan dalam variabel penelitian memiliki tingkat keandalan dalam kriteria tinggi. Sehingga butir-butir pertanyaan dalam variabel penelitian tersebut dapat digunakan untuk penelitian selanjutnya.

\subsection{Persepsi Responden terhadap Variabel Penelitian}

Variabel nilai perpustakaan $(\mathrm{X})$ terdiri atas 3 indikator, diantaranya adalah nilai ekonomi, nilai sosial, dan nilai akademik. Sementara variabel kepuasan mahasiswa terdiri dari 5 indikator diantaranya kecepatan layanan, shelving, empati, keramahan, dan kedisiplinan. Kuis/pertanyaan yang diajukan terhadap responden pada variabel nilai perpustakaan terdiri dari 11 butir pertanyaan, dan variabel kepuasan mahasiswa terdiri dari 6 butir pertanyaan. Setelah dilakukan uji validitas terbukti seluruh butir pertanyaan dinyatakan valid, sehingga 17 butir pertanyaan dapat digunakan untuk melakukan uji statistik. Oleh responden diberikan persepsi sebagaimana disajikan pada Tabel 9. 


\begin{tabular}{|c|c|c|c|c|c|}
\hline \multicolumn{6}{|c|}{$\begin{array}{l}\text { Tabel 9: Tingkat Persepsi Responden } \\
\text { terhadap Variabel Penelitian } \\
\qquad \mathrm{N}=135(2017)\end{array}$} \\
\hline Variabel & Indikator & $\begin{array}{c}\text { Skor } \\
\text { Jawa- } \\
\text { ban }\end{array}$ & $\begin{array}{l}\text { Skor } \\
\text { Total }\end{array}$ & $\begin{array}{l}\text { Nilai } \\
\text { Persep- } \\
\text { si }\end{array}$ & $\begin{array}{l}\text { Kuali- } \\
\text { fikasi }\end{array}$ \\
\hline \multirow{4}{*}{$\begin{array}{l}\text { Nilai } \\
\text { Perpus- } \\
\text { takaan }\end{array}$} & & 3,568 & 5,940 & 60,07 & Tingqi \\
\hline & $\begin{array}{l}\text { Nilai } \\
\text { Ekomi }\end{array}$ & 1171 & 1620 & 72,28 & Tinggi \\
\hline & $\begin{array}{l}\text { Nilai } \\
\text { Sosial }\end{array}$ & 1965 & 2700 & 72,78 & Tinggi \\
\hline & $\begin{array}{l}\text { Nilai } \\
\text { Akademik }\end{array}$ & 1194 & 1620 & 73,70 & Tinggi \\
\hline \multirow{7}{*}{$\begin{array}{l}\text { Kepua- } \\
\text { san } \\
\text { Mahasis- } \\
\text { wa }\end{array}$} & & 2375 & 3240 & 73,30 & Tinggi \\
\hline & $\begin{array}{l}\text { Kecepatan } \\
\text { Layanan }\end{array}$ & 419 & 540 & 77,59 & $\begin{array}{l}\text { Sangat } \\
\text { Tinggi }\end{array}$ \\
\hline & Shelving & 383 & 540 & 70,93 & Tinggi \\
\hline & Empati & 379 & 540 & 70,19 & Tinggi \\
\hline & $\begin{array}{l}\text { Kerama- } \\
\text { han }\end{array}$ & 395 & 540 & 73,15 & Tinggi \\
\hline & $\begin{array}{l}\text { Kecepa- } \\
\tan \end{array}$ & 392 & 540 & 72,59 & Tinggi \\
\hline & $\begin{array}{l}\text { Kedispli- } \\
\text { nan }\end{array}$ & 407 & 540 & 75,37 & $\begin{array}{c}\text { Sangat } \\
\text { Tinggi }\end{array}$ \\
\hline
\end{tabular}

Sumber: data primer diolah. Catatan: 0,01-25: Sangat Rendah; 25,01-50: Rendah; 50,01-75: Tinggi; 75,01-100: Sangat Tinggi

Pada Tabel 9 tampak, bahwa persepsi mahasiswa terhadap variabel nilai perpustakaan dalam kualifikasi tinggi dengan nilai persepsi sebesar 60,07 dan variabel kepuasan mahasiswa tergolong dalam kualifikasi tinggi pada angka persepsi sebesar 73,30 . Sementara indikator nilai akademik dalam kualifikasi tinggi dengan angka persepsi sebesar 73,70 dan terendah terdapat pada nilai ekonomi dengan skor72,28. Selanjutnya indikator kecepatan layanan menempati persepsi tertinggi 77,59 dalam kualifikasi sangat tinggi dan terendah pada indikator empati pada kualifikasi tinggi dengan angka persepsi sebesar 70,19.

Dari uraian tabel 9 diatas dapat dipahami bahwa ada hal-hal yang perlu ada perbaikan layanan yaitu pada aspek nilai ekonomi (dari indikator variabel nilai perpustakaan) dan aspek empati pada variabel kepuasan mahasiwa.

\subsection{Pengujian Korelasi}

Korelasi selain dapat untuk mengetahui derajat/ keeratan hubungan, juga dapat untuk mengetahui arah hubungan dua variabel numerik. Dalam penelitian ini akan dicari hubungan antara nilai Direktorat Perpustakaan UII dengan kepuasan mahasiswa UII.

Tabel 10: Hasil Uji Korelasi Nilai Perpustakaan terhadap Kepuasan $\mathrm{N}=135$ (2017)

\begin{tabular}{|c|c|c|c|}
\hline \multicolumn{4}{|c|}{ Correlations } \\
\hline & & $\begin{array}{c}\text { Nilai } \\
\text { Perpustakaan }\end{array}$ & $\begin{array}{l}\text { Kepuasan } \\
\text { Pemustaka }\end{array}$ \\
\hline \multirow{3}{*}{$\begin{array}{l}\text { Nilai } \\
\text { Perpusta- } \\
\text { kaan }\end{array}$} & $\begin{array}{l}\text { Pearson } \\
\text { Correlation }\end{array}$ & 1 & $.724^{* *}$ \\
\hline & Sig. (2-tailed) & & .000 \\
\hline & $\mathrm{N}$ & 135 & 135 \\
\hline \multirow{3}{*}{$\begin{array}{l}\text { Kepuasan } \\
\text { Mahasis- } \\
\text { wa }\end{array}$} & $\begin{array}{l}\text { Pearson } \\
\text { Correlation }\end{array}$ & $.724^{* *}$ & 1 \\
\hline & Sig. (2-tailed) & .000 & \\
\hline & $\mathrm{N}$ & 135 & 135 \\
\hline
\end{tabular}

** Correlation is significant at the 0.01 level (2-tailed). Sumber: Data Primer diolah

Dari hasil hitungan di atas diketahui bahwa terdapat pengaruh Nilai Perpustakaan UII (X) terhadap Kepuasan Mahasiswa UII (Y) dengan nilai signifikansi 0,000 0,05 $(0,000)$ lebih kecil dari 0,05). Sementara tingkat korelasi antara variabel $X$ dengan variabel $Y$ terdapat pengaruh sebesar $72,4 \%(0,724)$ dimana kriteria tingkat pengaruh (koefisien korelasi antar variable berkisar antara \pm 0.00 sampai $\pm 1,00$ dengan rincian sebagai berikut:

Tabel 11: Kriteria Tingkat Pengaruh antar Variabel

\begin{tabular}{l|cl}
\hline No & Skor Korelasi & \multicolumn{1}{c}{ Kategori Korelasi } \\
\hline 1 & $0,00-0,20$ & Hampir Tidak Ada Korelasi \\
2 & $0,21-0,40$ & Korelasi Rendah \\
3 & $0,41-0,60$ & Korelasi Sedang \\
4 & $0,61-0,80$ & Korelasi Tinggi \\
5 & $0,81-1,00$ & Artinya Korelasi Sempurna \\
\hline
\end{tabular}

Sumber: Sungadi (2018)

Dari hasil peneltian ini diperoleh hasil bahwa tingkat korelasi antara nilai perpustakaan terhadap kepuasan mahasiswa UII adalah sebesar $72,40 \%$ $(0,724)$. Artinya pengaruh kepuasan mahasiswa UII dari nilai perpustakaan sebesar $72,40 \%$, sementara masih ada faktor diluar nilai perpustakaan sebesar 
27,60\% yang mempengaruhi kepuasan mahasiswa.

Berdasarkan hasil uji korelasi tersebut diatas dapat disimpulkan bahwa dalam penelitian ini menerima hipotesis yang menyebutkan bahwa terdapat pengaruh antara nilai perpustakaan terhadap kepuasan mahasiswa UII dalam mendapatkan pelayanan. Sementara tingkat pengaruh nilai perpustakaan terhadap kepuasan mahasiswa UII pada kategori tinggi.

Untuk mengkaji lebih mendalam terhadap kepuasan pemustaka dari hanya sekedar melihat dari sisi nilai perpustakaan, oleh Jayasundara disarankan untuk lebih ditingkatkan kepada hal-hal yang lebih kompleks lagi. Dari hasil penelitiannya dia menjelaskan bahwa kepuasan pelanggan dari perspektif kualitas layanan di perpustakaan universitas jauh lebih kompleks daripada dikonseptualisasikan oleh alat saat ini, seperti LibQUAL, SURVPREF dan SERVQUAL. Akibatnya, penelitiannya telah menghasilkan model akhir yang paling baik digunakan untuk mengidentifikasi dan mengarahkan kegiatan penilaian praktis secara efisien di perpustakaan universitas, memungkinkan perpustakaan untuk mengevaluasi layanan mereka secara sistematis dan untuk mengidentifikasi area untuk peningkatan yang efektif. Selanjutnya, domain-domain ini menyediakan kerangka acuan bagi perpustakaan universitas untuk menilai kinerjanya. Struktur domain dari model eksklusif ini tidak dapat diamati pada model generik lainnya. Meskipun beberapa area berkualitas mungkin tidak memuaskan pelanggan, manajemen harus tetap mempertahankan tingkat kualitas yang mematuhi standar perpustakaan dan memperbaiki setiap kegagalan dari atribut ini, untuk mencegah efek yang merugikan pada kepuasan pemustaka.

Meskipun tidak mengurangi kepuasan pemustaka, dari penelitian lapangan sebelumnya, penelitian ini telah menunjukkan implikasi yang signifikan bagi para peneliti dan administrator perpustakaan dalam memahami pentingnya domain kepentingan individual dalam spektrum layanan perpustakaan pergruan tinggi, untuk memberikan kepuasan tertinggi bagi pelanggan dengan layanan perpustakaan berkualitas.

\section{Penutup}

Dari hasil olah data penelitian dapat disimpulkan bahwa persepsi responden terhadap nilai perpustakaan UII dalam kualifikasi tinggi dengan skor 60,07 dan kepuasan mahasiswa UII dalam kategori tinggi dengan angka 73,30.

Sementara dari hasil analisis korelasi terbukti bahwa terdapat pengaruh nilai perpustakaan terhadap kepuasan mahasiswa hasil studi empiris pada Direktorat Perpustakaan UII, sehingga hipotesis penelitian ini diterima.

Rekomendasi bagi Direktorat Perpustakaan UII ada hal-hal yang perlu ada perbaikan layanan yaitu pada aspek nilai ekonomi (dari indikator variabel nilai perpustakaan) dan aspek empati pada variabel kepuasan mahasiwa. Perbaikan nilai ekonomi menyangkut hal-hal antara lain: (i) adanya keseimbangan layanan yang diperoleh oleh mahasiswa dengan biaya, waktu, dan usaha yang telah dikeluarkan; (ii) informasi yang diperoleh mahasisea merupakan investasi yang sangat bermanfaat dalam menunjang proses penyelesaian kuliah, sehingga diperlukan infoemasi yang benarbenar berkualitas dan relevan; (iii) dengan biaya kuliah yang sudah dikeluarkan, para mahasiswa akan mengoptimalkan dalam pemanfaatan layanan perpustakaan. Sementara empati yang diperlukan mahasiswa adalah dalam bentuk bantuan dari petugas perpustakaan ketika mahasiswa mengalami kesulitan dalam mencari dan menemukan koleksi/ informasi yang dibutuhkan.

\section{Daftar Pustaka}

Bilandzic, M., \& M. Foth. Learning beyond booksstrategies for ambient media to improve libraries and collaboration spaces as interfaces for social learning. Multimedia Tools and Applications, 71 
(1) (2014), pp. 77-95

Bolton, R.N., Lemon, K.N., \& Verhoe, P.C. 2004. The theoretical underpinnings of customer asset management: A framework and propositions for future research. Journal of the Academy of Marketing Science, 32 (3) (2004), pp. 271-292.

Brady, M.K., Cronin, J. \& R.R. Brand. 2002. Performance-only measurement of service quality: A replication and extension. Journal of Business Research, 55 (1) (2002), pp. 17-31.

British Library. Measuring our value. Available https://www.bl.uk/aboutus/stratpolprog/ increasingvalue/measuringourvalue_full.pdf (2004), Accessed 20th Apr 2018.

Brown, S., \& Swartz, T. 1989. A gap analysis of professional service quality. Journal of Marketing, 53 (2) (1989), pp. 92-98.

Cullen, M. Collaboration in libraries and learning environments.The Australian Library Journal, 63 (4) (2014), pp. 325-326.

Fialkoff, F. We don't need Google. Library Journal, 136 (7) (2011).

Grönroos, C. 1984. A service quality model and its market implications. European Journal of Marketing, 18 (4) (1984), pp. 36-44.

Grönroos, C. 1990. Service management and marketing: Managing the moments of truth in service competition. Jossy Press, San Francisco (1990).

Hernon, P., \& Altman, E. Assessing service quality: Satisfying the expectations of library customers. American Library Association, Chicago (1998).

Homburg, C. \& X. Luo. 2007. Neglected outcomes of customer satisfaction. Journal of Marketing 71 (2007), pp. 133-149.

lacobucci, D., Ostrom, A., \& Grayson, K. Distinguishing service quality and customer satisfaction: The voice of the customer. Journal of Consumer Psychology, 4 (3) (1995), pp. 277-303.

Jayasundara, Chaminda. Business Domains for Boosting Customer Satisfaction in Academic
Libraries. The Journal of Academic Librarianship Volume 41, Issue 3, May 2015, Pages 350-357.

Jolly, L., \& White, S. Communication, collaboration, and enhancing the learning experience: Developing a collaborative virtual enquiry service in university libraries in the north of England. New Review of Academic Librarianship, 22 (2-3) (2016), pp. 176-191.

Kotler, P. 1997. Manajemen Pemasaran. Edisi Bahasa Indonesia - revisi. Jilid pertama. Jakarta: PT Prenhanlindo

Little, G. The revolution will be streamed online: Academic libraries and video. The Journal of Academic Librarianship, 37 (1) (2011), pp. 70-72.

Lupiyoadi, Rambat. 2001. Manajemen Pemasaran Jasa Teori dan Praktek. Jakarta: Salemba Empat

Maddern, H., Maull, R., Smart A., Baker, P. 2007. Customer satisfaction and service quality in UK financial services. International Journal of Operations \& Production Management, 27 (9) (2007), pp. 999-1019.

Matthews, J.R. Valuing information services and the library: Possibilities and realities. Libraries and the Academic., 8 (4) (2008), pp. 91-112

Mitchell, R.C., \& R.T. Carson. Using surveys to value public goods: The contingent valuation method (1st ed.), Resources for the Future, Washington (1989).

Odling-Smee, L. Online resources threaten livelihood of libraries. Nature, 446 (7139) (2007), pp. 958-959.

Oliver, R.L. Satisfaction: A behavioural perspective on the consumer. McGraw-Hill, New York (1997).

Palfrey, J. 2015 BiblioTech: Why libraries matter more than ever in the age of Google. Basic Books, New York (2015).

Parasuraman, A., Zeithaml, V.A., \& Berry, L.L. SERVQUAL: A multiple-item scale for measuring consumer perceptions of service quality. Journal of Retailing, 64 (1) (1988), pp. 12-40.

Pateman, J. Managing cultural change in public libraries. Public Library Quarterly, 36 (3) (2017), 
pp. 213-227, 10.1080/01616846.2017.1318641.

Poll, R. Impact/outcome measures for libraries. Liber Quarterly, 13 (2003), pp. 329-342

Pung, C., Clarke, A., \& Patten. Measuring the economic impact of the British library. New Review of Academic Librarianship, 10 (1) (2007), pp. 79-102, 10.1080/13614530412331296826

Rapp, D. Survey: Online libraries have "greatest impact". Library Journal, 136 (5) (2011), p. 20.

Rooney-Browne, C. Methods for demonstrating the value of public libraries in the UK: A literature review. Library \& Information Research, 35 (109) (2011), pp. 3-39.

Row-Farr, J. A place free of judgement - A teenage takeover of libraries ('Why Are You Here Teenager?'). Performance Research, 22 (1) (2017), pp. 91-92.

Rudzioniene, J. Collaboration in libraries and learning environments. (2014). The Electronic Library, 32 (6) (2014), pp. 923-924.

Sbaffi, L., \& J. Rowley. Public libraries and non-users: A comparison between Manchester and Rome. Journal of Librarianship and Information Science, 47 (2) (2014), pp. 104-116.

Schneider, B., \& White, S.S. Service quality: Research perspective. Sage, Thousands Oaks, CA (2004).

Sedarmayanti. 2005. Manajemen Sumber Daya Manusia. Yogyakarta: Pustaka Pelajar.

Sharma, J.C. Total quality management in library and information services. S.M. Dhawan (Ed.), Quest for quality, Indian Library Association, Delhi (2001), pp. 166-171.

Stojanovski, J. Higher education and research libraries: Why do we need them more than ever? Kemija u Industriji, 62 (11) (2013), pp. 452-455.

Sugiyono. 2010. Statistika untuk Penelitian. Bandung : Alfabeta.

Tenopir, C. Measuring value and ROI of academic libraries: The IMLS Lib-Value Project (2011). (Available at: www. york.ac.uk/media/abouttheuniversity/ supportservices/informationdirectorate/ documents/northumbriapresentations/ NorthumbriaTenopirfinal.2011.pptx) [2018, March 3]

Tessler, A. Economic valuation of the British Library Oxford Economics (2013). Available:

https://www.bl.uk/aboutus/stratpolprog/ increasing value/britishlibrary_ economicevaluation.pdf, Accessed 20th Apr 2018.

Town, J.S. Assessing outcomes and value: it's all a matter of perspective. Performance Measurement and Metrics, 16 (3) (2015), pp. 211-233, 10.1108/ PMM-10-2015-0034.

Town, J.S. Implementing the value scorecard. Performance Measurement and Metrics, 16 (3) (2015), pp. 234-251. https://doi.org/10.1108/ PMM-10-2015-0033.

Walker, C., et. al. Measuring the value of Public Libraries: The fallacy of footfall and issues as measures of the value of Public Libraries. Available: https://www.sheffield.ac.uk/ polopoly_fs/1.199926!/file/Measuringthevalue ofpubliclibraries.pdf (2012), Accessed 4th May 2018.

White, L.N. Aligning library assessment processes to the library's service environment: A conceptual model. Library Review, 57 (7) (2008), pp. 499-513, 10.1108/00242530810894022

Yanez, J.A.G. The Economic and Social Value of Information Services: Libraries - Report of findings. Online.

http://www.fesabid.org/documentos/economic social_value_information_service_libraries.pdf (2014), Accessed 3rd Apr 2018. 